\title{
Retinal neovascularization, collaterals, and vascular shunts
}

\author{
PAUL HENKIND AND GEORGE N. WISE \\ From the Department of Ophthalmology of the Albert Einstein College of Medicine/Montefiore \\ Hospital and Medical Center, New York
}

Contributed by request and dedicated to Sir Stewart Duke-Elder

Retinal vascular disorders are a leading cause of human visual impairment. It is only within the past decade, however, that methodologies such as fluorescein angiography (Novotny and Alvis, r96r) and retinal digestion (Kuwabara and Cogan, r96o) have been developed which permit us accurately to delineate the various features of retinal vascular disease. We must remember that retinal vascular responses to abnormal situations are remarkably limited; understanding these responses will aid us in the diagnosis and management of retinal vascular disease. In our experience, we find that ophthalmologists often confuse the three entities, neovascularization, collateralization, and shunt formation. Each has a different appearance, different aetiology, and a different prognosis. We will demonstrate the significant features of each type, placing it in its proper clinical context. It is first necessary to define each entity (Table, overleaf):

\section{(I) Retinal neovascularization.}

These are new vessels originating from and contiguous with the pre-existing retinal vascular bed. They are located either within or adjacent to the retina, in areas where vessels are not normally present.

(2) Retinal collaterals

These are vessels which develop within the framework of the existing retinal vascular network. Collaterals originate from the retinal capillary bed, joining obstructed to nonobstructed adjacent vessels, or by-passing obstructions in a single vessel; i.e. veins are linked to veins, arteries linked to arteries, and, less frequently, arteries are joined to veins. Flow through these channels is generally slow, rarely normal.

\section{(3) Retinal vascular shunts}

These are arteriovenous communications, congenital or developmental, in which blood passes directly from artery to vein without going through the normal capillary bed. Flow in these vessels is usually rapid, but may be slow if the shunt is fed by a vessel with a reduced flow.

The common denominator which binds retinal neovascularization, collaterals, and shunts is the fact that each appears ophthalmoscopically and angiographically as an abnormal vascular channel either within or adjacent to the retina.

\section{RETINAL NEOVASGULARIZATION}

The most significant of the three entities clinically, this occurs as a result of some stimulus, the nature of which is not known, provoking pre-existing retinal vessels to proliferate abnormally. The stimulus appears to be related to situations involving poor retinal nutrition resulting in retinal hypoxia and/or the accumulation of metabolic products. Retinal

\footnotetext{
Address for reprints: P. Henkind, M.D., Department of Ophthalmology, Montefiore Hospital and Medical Center, 111 East 210 th Street, Bronx, New York 10467, U.S.A.

This work was assisted by Grant \# EY00613-3 from the National Institutes of Health, Department of Health, Education and Welfare.
} 
Table Differential characteristics of retinal neovascularization, collaterals, und shunts

\begin{tabular}{|c|c|c|c|c|}
\hline Condition & Origin/Aetiology & $\begin{array}{l}\text { Appearance } \\
\text { (ophthalmoscopic) }\end{array}$ & $\begin{array}{l}\text { Fluorescein } \\
\text { angiography }\end{array}$ & Histopathology \\
\hline Neovascularization & $\begin{array}{l}\text { Developmental } \\
\text { Occurs in presence of } \\
\text { vascular embarr- } \\
\text { assment } \\
\text { Grows from retinal } \\
\text { vessels into area(s) } \\
\text { without such vessels }\end{array}$ & $\begin{array}{l}\text { Leashes or tufts of } \\
\text { vessels upon or } \\
\text { above retinal } \\
\text { surface } \\
\text { Associated connective } \\
\text { tissue may be } \\
\text { clinically invisible }\end{array}$ & $\begin{array}{l}\text { Abnormal appearing } \\
\text { tortuous vessels, } \\
\text { which leak } \\
\text { fluorescein } \\
\text { May fill early if fed by } \\
\text { an arteriole } \\
\\
\text { Associated connective } \\
\text { tissue stains later } \\
\text { Adjacent intraretinal } \\
\text { vascular bed } \\
\text { usually abnormal }\end{array}$ & $\begin{array}{l}\text { Thin walled, irregular } \\
\text { vessels upon retinal } \\
\text { surface and within } \\
\text { vitreous cavity } \\
\text { May also develop } \\
\text { subretinally }\end{array}$ \\
\hline Collaterals & $\begin{array}{l}\text { Developmental } \\
\text { Occur after block of } \\
\text { either artery, vein, } \\
\text { or capillary bed } \\
\text { Develop from and } \\
\text { utilize pre-existing } \\
\text { retinal capillary bed }\end{array}$ & $\begin{array}{l}\text { Intraretinal vascular } \\
\text { channels, generally } \\
\text { tortuous, which } \\
\text { link blocked vessel } \\
\text { with nearest patent } \\
\text { vessel of like type in } \\
\text { case of arterial or } \\
\text { venous block } \\
\text { A-V type in capillary } \\
\text { blockage } \\
\text { May bypass a block as } \\
\text { in duplicated } \\
\text { channel }\end{array}$ & $\begin{array}{l}\text { Tortuous channel } \\
\text { linking a blocked } \\
\text { with a patent } \\
\text { vessel, or bypassing } \\
\text { an obstructive site } \\
\text { Usually slow or } \\
\text { moderate flow } \\
\text { Rarely any leak } \\
\text { Adjacent vascular bed } \\
\text { abnormal }\end{array}$ & $\begin{array}{l}\text { Vessels with same } \\
\text { characteristics as } \\
\text { channels they link } \\
\text { Occupy inner retinal } \\
\text { layers }\end{array}$ \\
\hline \multirow[t]{2}{*}{ Shunts } & Congenital & $\begin{array}{l}\text { Large vascular } \\
\text { channels, usually } \\
\text { larger than normal } \\
\text { retinal vessels } \\
\text { May be difficult to } \\
\text { distinguish arterial } \\
\text { from venous limb, } \\
\text { because blood is } \\
\text { little altered in } \\
\text { retinal transit }\end{array}$ & $\begin{array}{l}\text { Large, rapidly filling } \\
\text { vascular channels } \\
\text { In area of shunt there } \\
\text { is no interposed } \\
\text { capillary bed } \\
\text { No leakage of dye } \\
\text { from these vessels }\end{array}$ & $\begin{array}{l}\text { Large, thin-walled } \\
\text { vessels } \\
\text { May occupy entire } \\
\text { retinal thickness, } \\
\text { and even protrude } \\
\text { from retinal surface }\end{array}$ \\
\hline & Developmental & $\begin{array}{l}\text { May be large channels } \\
\text { in angiomatous } \\
\text { malformations } \\
\text { Small channels in } \\
\text { Takayasu's disease }\end{array}$ & $\begin{array}{l}\text { Leakage from } \\
\text { vascular malfor- } \\
\text { mation may be } \\
\text { profuse or mild } \\
\text { Feeding and draining } \\
\text { vessels usually do } \\
\text { not leak }\end{array}$ & $\begin{array}{l}\text { Variably enlarged } \\
\text { vascular channels }\end{array}$ \\
\hline
\end{tabular}

neovascularization occurs in retinal vein occlusion, some haemoglobinopathies (especially haemoglobin sickle cell disease), Eales's disease, diabetic retinopathy, sarcoidosis, pulseless disease, and retrolental fibroplasia (Wise, Dollery, and Henkind, I97I). In all but the latter, the neovascularization develops from a mature vascular bed that has been com-? promised by an impediment to flow. In retrolental fibroplasia, the neovascularization 3 develops from an immature retinal vascular bed in which oxygen in high concentration has 8 caused retinal vasoconstriction and vaso-obliteration (Ashton, 1966); when the oxygen

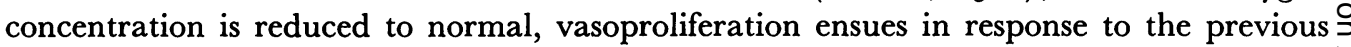
impedance of retinal vascular flow. In situations in which the circulation is totally com- $-\frac{7}{0}$ promised, such as retinal artery occlusion, retinal neovascularization does not occur.

The reason for this is presumably the fact the retinal cells are dead, and cannot provide $N$ the stimulus necessary for neovascularization. The fact that the retinal vascular cells are $\tilde{O}^{\circ}$ themselves dead and are thus unable to proliferate, may also be a significant factor.

Retinal neovascularization usually appears most often at the disc and near the larger 2 retinal veins, but may develop from any point in the retinal vascular bed, and grow either $\stackrel{0}{\circ}$ superficially towards the vitreous, or downwards beneath the retina. Early neovasculariza- $\stackrel{\infty}{?}$ tion may appear as tufts of irregular, fine vessels on the retinal surface (Fig. I). These new 0 vessels may remain localized; they may grow profusely and proliferate into large fronds $\stackrel{\vec{D}}{\mathbb{D}}$ and complexes, or on rarer occasions they may collapse and become fibrotic and quiescent $\frac{\Omega}{D}$ (Fig. 2). Even at their most developed they appear to be of relatively thin calibre. Their $\frac{\varrho}{\sigma}$ mantle of connective tissue, clinically invisible at first, may soon become readily apparent, 


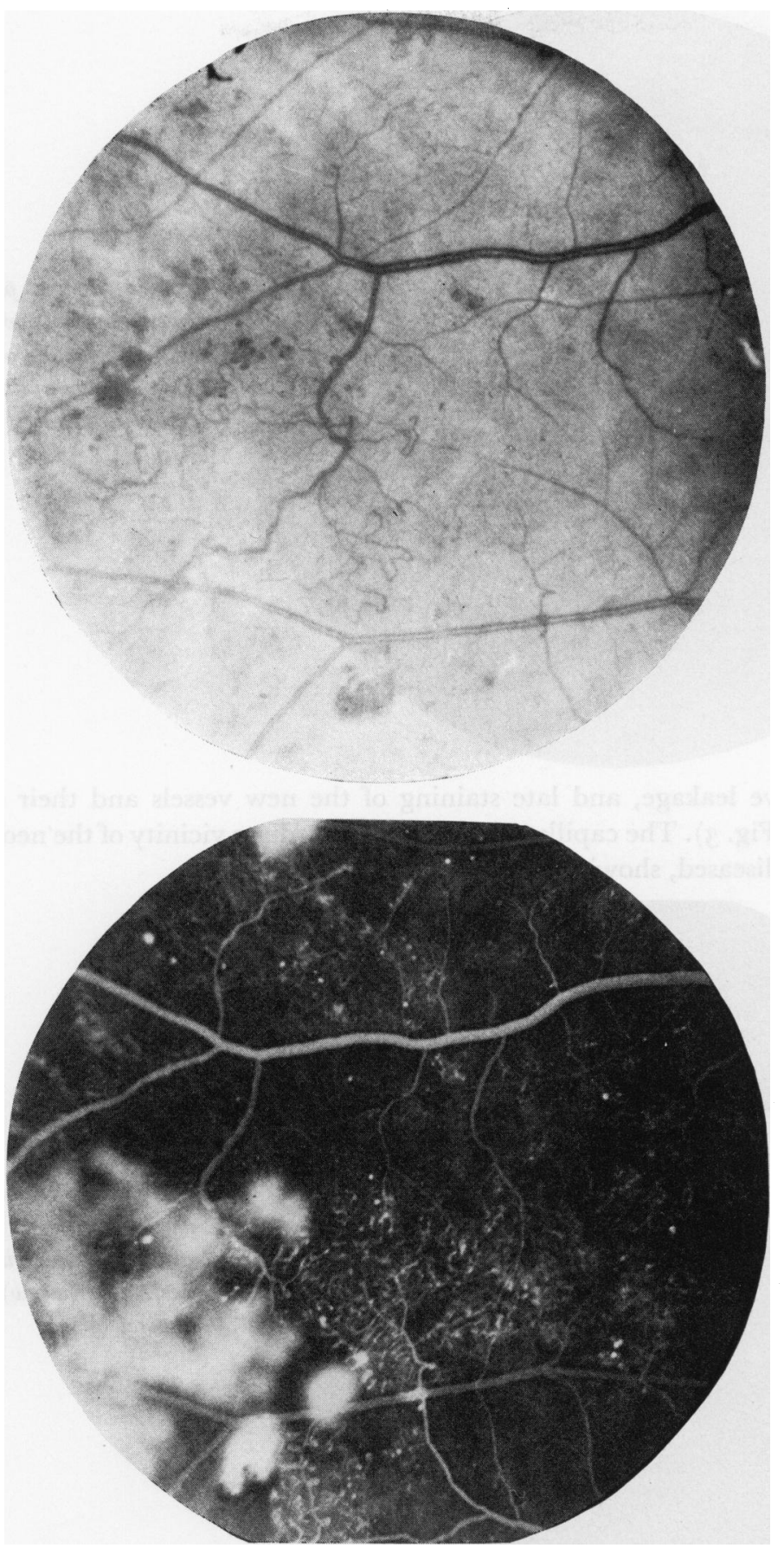

FIG. I (a) Fundus photograph of a diabetic subject with early retinal neovascularization. The new vessels appear as irregular, fine, tortuous channels upon the inner retinal surface

(b) Fluorescein angiogram of same area as shown in Fig. I a. Note that new vessels lie in areas of capillary bed non-perfusion, and that they leak fluorescein

and, in late stages may predominate.

Retinal neovascularization is the most frequent cause of vitreous haemorrhage, but it does not arise as a consequence of the bleeding, as was once thought. Fluorescein angiography demonstrates the irregular nature of the neovascularization. One finds abnormal 
FIG. 2 Fundus photograph of a

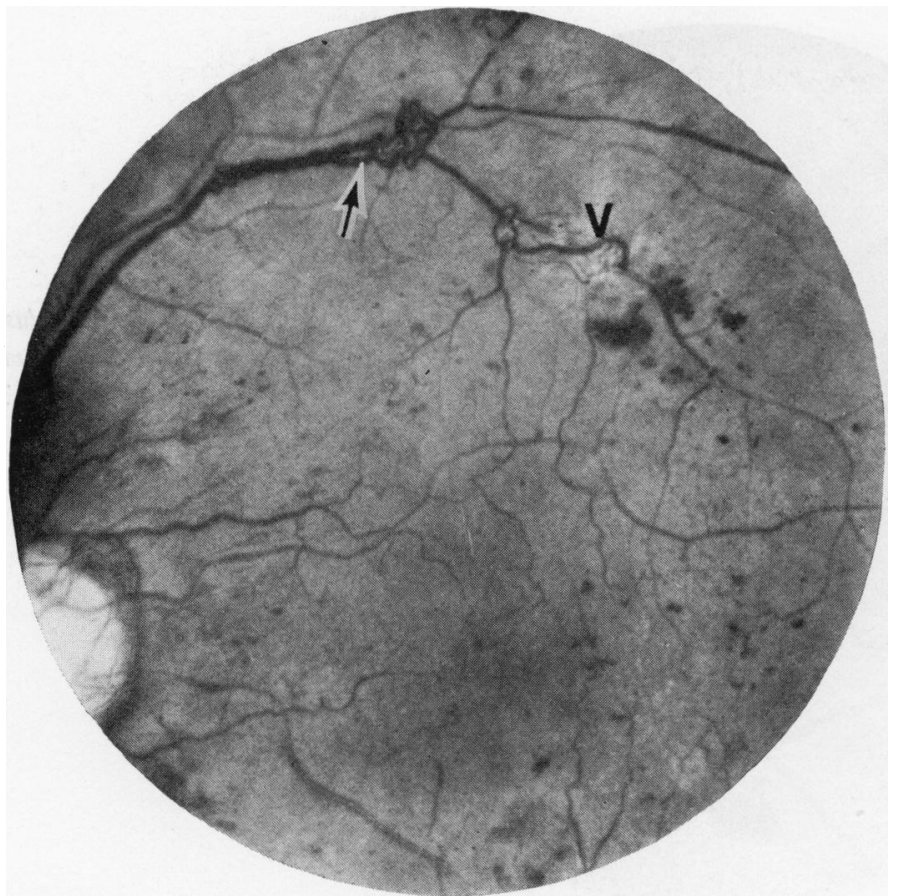

diabetic subject with pronounced neovascularization originating from superotemporal vein (arrow). A venous collateral $(V-V)$ is also present $(V)$

filling patterns, dye leakage, and late staining of the new vessels and their surrounding connective tissue (Fig. 3). The capillary bed in the immediate vicinity of the neovascularization is invariably diseased, showing evidence of poor perfusion.

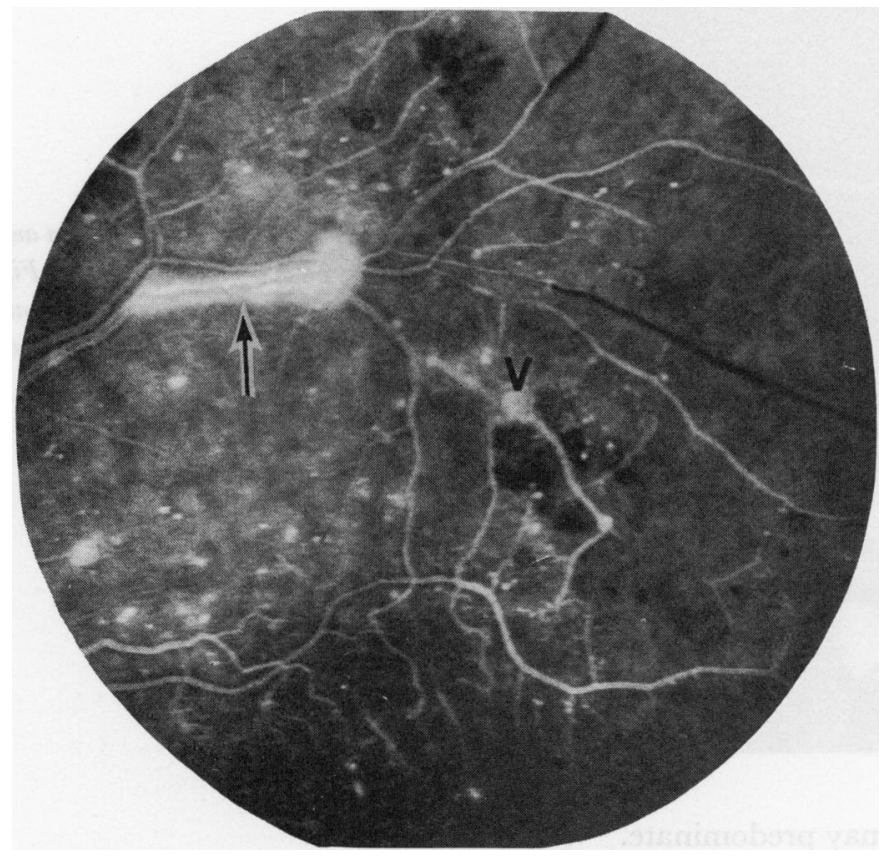

FIG. 3 Fluorescein angiogram of same area as shown in Fig. 2. Note leakage of fluorescein from neovascularization (arrow), but not from collateral $(V)$

The most important sequelae of retinal neovascularization are repeated haemorrhages in the surrounding tissue, mainly the vitreous space, and secondary retinal distortion and detachment, For these reasons, treatment is directed towards elimination of these neovascu- 
lar elements, and this is best accomplished by photocoagulation.

Experimental production of retinal neovascularization other than in retrolental fibroplasia, has been rare. Imre ( 1964 ) claims to have induced retinal neovascularization by injecting lactic acid into the vitreous bodies of neonatal kittens. Baum and Wise (1966) experimentally produced subretinal fibrovascular proliferation in adult cats. Unfortunately convincing retinal neovascularization has not been demonstrated in any animal model of diabetes.

RETINAL GOLLATERAL VESSELS

These develop from the existing retinal capillary network in situations where one or more vessels become occluded but adjacent vascular channels are patent and functioning. Three types of collaterals have been noted: arterio-arteriolar (A-A) which develop after branch artery obstruction; veno-venular (V-V) which develop after vein obstruction; and arteriovenous $(\mathrm{A}-\mathrm{V})$ which occur in situations of capillary bed obstruction. The latter occur most particularly in diabetic retinopathy, long-standing glaucoma, Leber's multiple miliary aneurysms, and in some cases of sickle cell retinopathy. It would appear that collaterals result from haemodynamic factors, possibly a combination of enhanced flow and increased intravascular pressure within the capillary network adjacent to an obstructed vessel. It is presumed that any capillary channel can be transformed into a larger calibre vessel, either arteriole or venule, if circumstances are favourable for it to do so. Whether there are biochemical factors in addition is unknown. Collaterals are initially rather meandering in course. In time they may straighten as more circuitous routes are abandoned; the collateral vessel may assume the same calibre and cellular characteristics of the vessel whose function it replaces. Collaterals may also disappear if the obstructed vessel reopens. It is unusual for collateral vessels to leak fluorescein, except in their earliest stages of development. This is in contradistinction to retinal neovascularization, which is always permeable to fluorescein. Furthermore, collaterals have no tendency to extend outside the retinal level in which they originate.

Venous collaterals (V-V), the most frequent type of collateral seen ophthalmoscopically, develop via the deep capillary bed. This is because the deep capillary bed is more venous in character than the superficial network. They may be observed several weeks after venous obstruction, and are most often seen after branch vein occlusion (Fig. 4). Venous collaterals develop upon or within the optic disc of patients with central retinal vein occlusion, but in this instance the collaterals develop between the obstructed disc head capillaries (which normally drain into the blocked central retinal vein) and the unobstructed choroidal or pial capillaries draining into patent venous channels. V-V collaterals have been induced in arterial embolization experiments in cats (Henkind, I966). This suggests that reduced retinal arterial perfusion may be equivalent to direct obstruction of retinal veins. Photocoagulation has been used to occlude retinal veins experimentally, with secondary development of V-V collaterals (Kohner, Dollery, Shakib, Henkind, Paterson, de Oliveira, and Bulpitt, I970).

Arterial collaterals (A-A) are observed less frequently in human disease than their venous counterparts. They may occur after branch artery occlusion but are rare after central retinal artery occlusion. They may be seen within weeks after an arteriole becomes occluded, but they develop too late to reverse the effects of the occlusion (Fig. 5). Thus, they serve more as a marker of previous arterial obstructive disease than as a protective mechanism (on the other hand, venous collaterals may help to preserve retinal function in the areas in which they form). Arterial collaterals are relatively easy to produce in experimental 
FIG. 4 Fundus photograph showing a venous $(V-V)$ collateral channel which developed after a branch vein occlusion. The occlusion occurred at the site of $A-V$ crossing (arrow). The collateral $(V)$ joins an obstructed branch with a patent venous branch closer to the disc

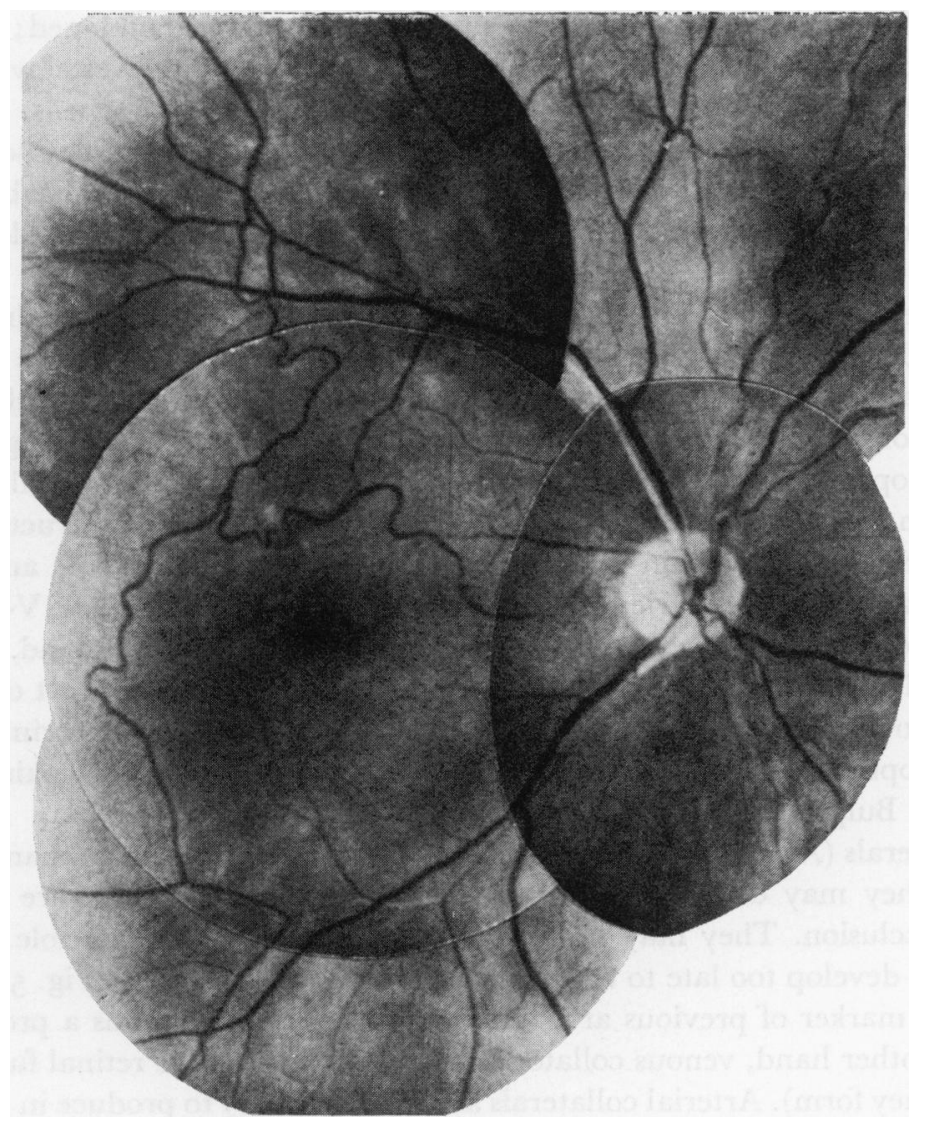

FIG. 5 Retinal arteriolar collaterals in a $3^{1-y e a r-o l d ~ m a l e ~}$ with severe hypertension and presumed multiple branch artery occlusions (From Ball and Henkind, 1967) 
animals like pigs, cats, and monkeys, and their cellular and physiological properties have been studied (Henkind, I966; Dollery, Henkind, Paterson, Ramalho, and Hill, I966; Klein, Klein, Henkind, and Bellhorn, I97 I).

Arterio-venous collaterals (A-V) have been noted clinically in patients with sickle cell haemoglobinopathies and Leber's multiple miliary aneurysms. Cogan and Kuwabara (1963) were impressed by the prominence of what they termed "capillary shunts" in diabetic retinopathy. They noted, in retinal digest preparations, vessels larger than capillaries traversing large areas of capillary closure and linking a patent retinal artery and vein. Such vessels can be demonstrated by fluorescein angiography (Wise and others, I97 I)

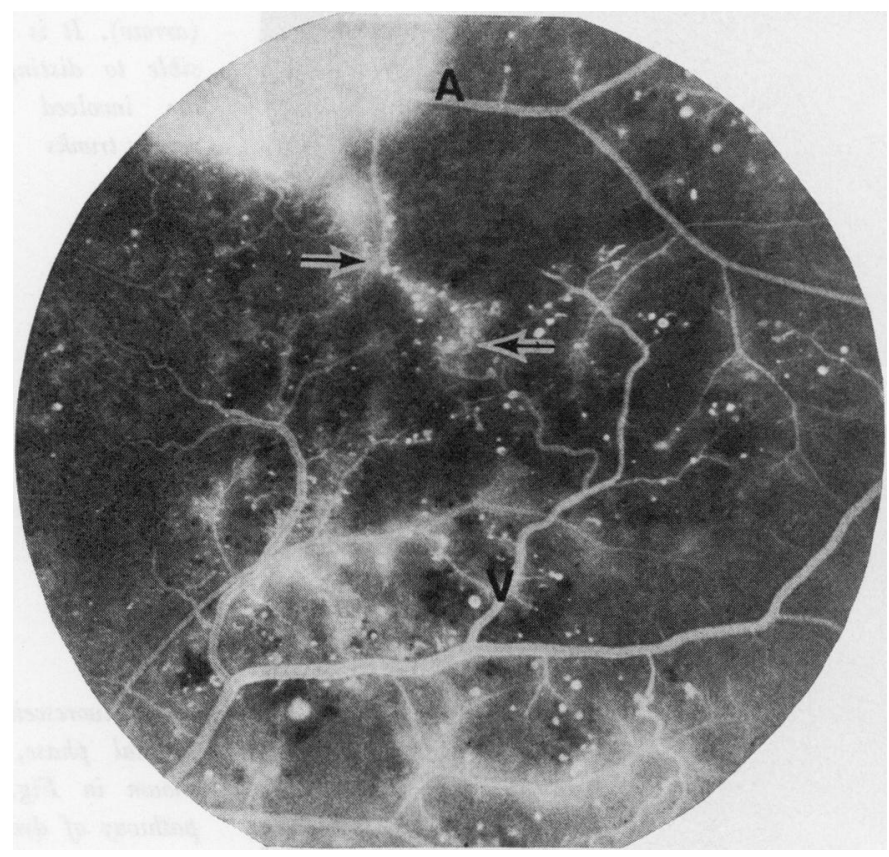

FIG 6 Fluorescein angiogram of a diabetic patient, demonstrating an arterio-venous $(A-V)$ collateral (arrows) traversing a large area of retinal capillary bed closure and linking a patent retinal artery $(A)$ and vein $(V)$

and usually have a slow rate of flow (Fig. 6). Contrary to the opinion of Cogan and Kuwabara ( 1963 ), we feel that these are collateral vessels which develop as a result of obliteration of the retinal capillary bed, and that they are not the cause of the capillary closure per se. Collaterals of similar appearance have been demonstrated in digest preparations of longstanding glaucomatous eyes where the capillary bed has become virtually obliterated. A-V collaterals develop, therefore, to permit blood to cross from the arterial to the venous side of the retinal circulation in situations where the capillary circulation has been primarily impaired.

Collateral vessels can be said to represent an attempt to restore normal flow in the retinal vascular bed. They should not be treated by photocoagulation, for their destruction can only lead to further retinal circulatory embarrassment.

\section{RETINAL VASGULAR SHUNTS}

The purest form of retinal vascular shunt is the racemose angioma, a congenital lesion, in which there is a direct anastomosis between a retinal artery and vein (Duke-Elder, 1964) (Fig. 7). The vessels are invariably dilated and tortuous, occupy almost the full retinal thickness, have a high flow rate, and do not leak fluorescein. Histological examination of 
such cases is rare. One example in a rhesus monkey had very thin-walled vessels (Bellhorn, Friedman, and Henkind, 1972). These shunts are apparently stationary and do not cause progressive retinal damage.

This lesion is to be contrasted with shunts seen in retinal angiomatosis (von Hippel's disease) or Coats's disease (Fig. 8). In these instances, previously normal channels enlarge to carry additional blood to a distal vascular malformation. The retina in the area of the malformation often shows marked alterations, with exudative and haemorrhagic lesions.

FIG. 7(a) Congenital retinal arterio-venous shunt. There is a direct communication between the artery and vein without an interposed cupillary bed (arrow). It is almost impossible to distinguish between the involved arterial and venous trunks

(b) Fluorescein angiogram, arterial phase, of the area shown in Fig. 7(a). Note pathway of dye directly from artery $(A)$ to vein $(V)$. The former has an irregular luminal calibre 


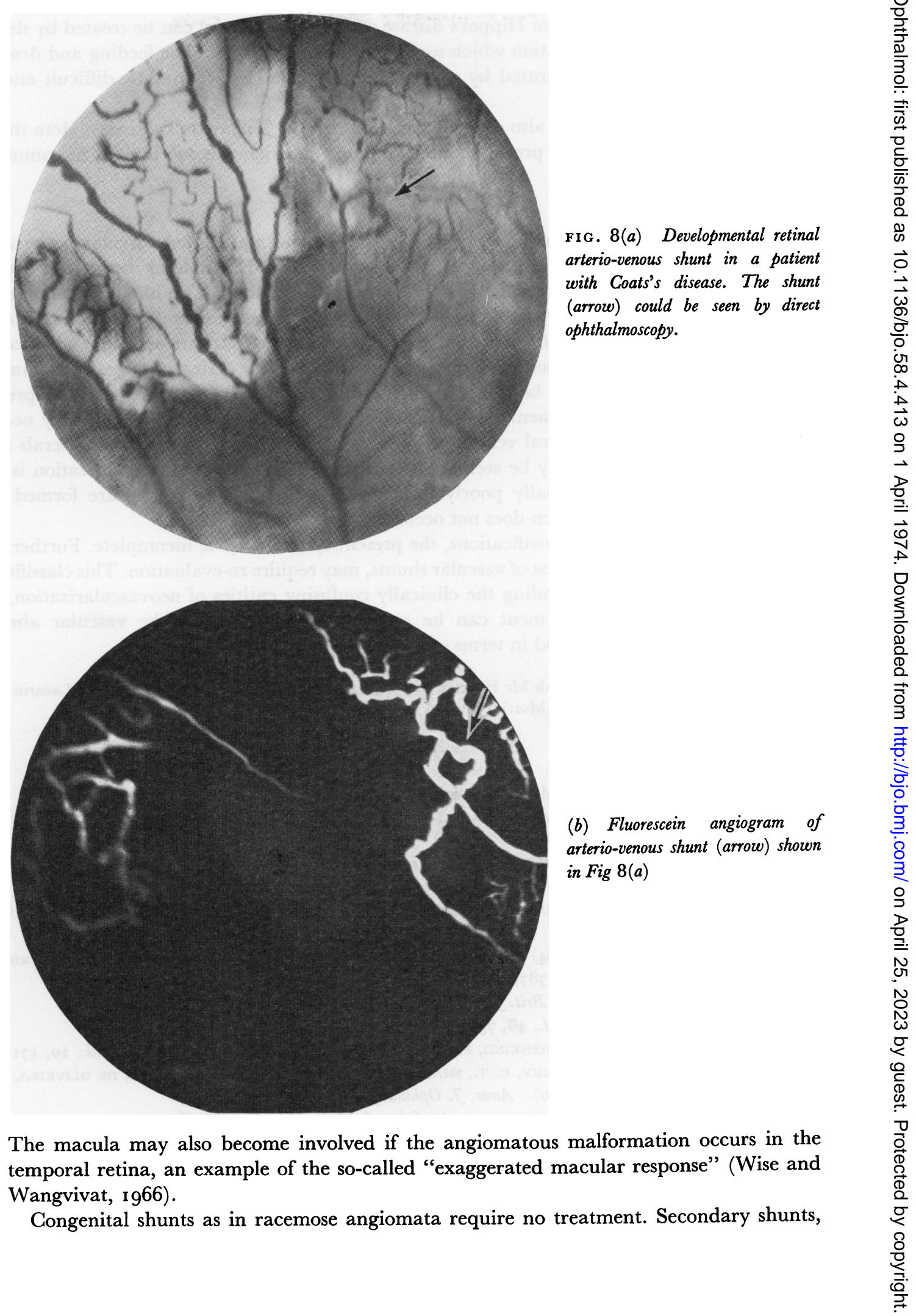


such as occur in von Hippel's disease and Coats's disease, can be treated by destroying the vascular malformation which usually contains the shunt. The feeding and draining vessels need not be obliterated by photocoagulation; indeed, it may be difficult and dangerous to do so.

Vascular shunts also occur in pulseless disease (Takayasu's disease). Here they probably represent true low pressure shunts, but our experience is too limited to comment further.

\section{Discussion}

In the previous section we described three abnormal retinal vascular patterns as distinct $\vec{\circ}$ entities and, in most instances, the clinician should be able to distinguish between them. There may be occasions, however, when this is difficult. While ophthalmoscopy or slit- $\mathrm{G}$ lamp examination will often suffice, it may be necessary to employ fluorescein angiography to assist in proper diagnosis and management. Also, there are occasions when combinations of the abnormal vascular patterns coexist in a single retinal disease. For example, in diabetic retinopathy, both neovascularization and A-V collaterals may be present in the $\frac{\vec{\omega}}{\omega}$ same fundus. In haemoglobin sickle cell disease, neovascular seafans may occur in areas 음 adjacent to collateral vessels. In branch vein occlusion, both $\mathrm{V}-\mathrm{V}$ collaterals and neovascular elements may be seen together. Here, however, if neovascularization is prominent, collaterals are usually poorly formed. Conversely, if collaterals are formed early, neovascularization often does not occur.

As in all new classifications, the present system may be incomplete. Further knowledge, especially in the area of vascular shunts, may require re-evaluation. This classification seems useful in understanding the clinically confusing entities of neovascularization, collaterals, and shunts. Treatment can be rationally planned when the vascular abnormality is properly understood in terms of its aetiology and natural history.

We should like to thank Mr Henrick Malpica for the illustrations, and Mrs Jeanette Lazarin for secretarial assistance. Dr. Donald Morris provided useful criticism.

\section{References}

Ashton, n. (1966) Amer. 7. Ophthal., 62, 412

BELLHORN, R. W., FRIEDMAN, A. H., and HENKIND, P. (1972) Ibid., 74, $5^{17}$

BALL, C. J., and HENKIND, P. (1967) Brit. F. Ophthal., 51, 688

BAUM, J. L., and WISE, G. N. (1966) Ibid., 61, 528

COGAN, D. G., and KUWABARA, T. (1963) Diabetes, 12, 293

DOLleRY, C. T., HENKIND, P., PATERSON, J. W., RAMALHO, P. S., and hill, D. W. (Ig66)

50, 285

DUKE-ELDER, s. (1964) "System of Ophthalmology", vol. 3, part 2, "Normal and Abnormal

Development", p. 787. Kimpton, London

HENKIND, P. (1966) Brit. J. Ophthal., 50, 482

IMRE, G. (I964) Ibid., 48, 75

KLEIN, R., KLEIN, B., HENKIND, P., and BELLhORN, R. W. (I97I) Invest. Ophthal., 10, $47 \mathrm{I}$

KOHNER, E. M., DOLLERY, C. T., SHAKIB, M., HENKIND, P., PATERSON, J. W., DE OLIVEIRA, L. N. F., and $\mathscr{\complement}$

BUlpitT, C. J. (1970) Amer. 7. Ophthal., 69, 778

kuwabara, T., and cogan, D. G. (1960) A.M.A. Arch. Ophthal., 64, 904

NOVOTNY, H. R., and ALVIS, D. L. (I96I) Circulation, 24, 82

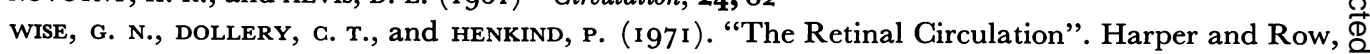

New York 